Water Policy 9 Supplement 2 (2007) 83-97

\title{
Community-based natural resource management: governing the commons
}

\author{
C. Fabricius ${ }^{\mathrm{a}}$ and S. Collins ${ }^{\mathrm{b}}$ \\ ${ }^{a}$ Corresponding author. Department of Environmental Science, Rhodes University, PO Box 94, 6140, Grahamstown, \\ South Africa. Current address: Nelson Mandela Metropolitan University, Saasveld Campus, 6530 George, South Africa \\ E-mail:christo.fabricius@nmmu.ac.za
}

${ }^{b}$ GTZ Transform, PO Box 13732, Hatfield, 0028, Pretoria, South Africa

\begin{abstract}
Community-based Natural Resource Management (CBNRM) focuses on the collective management of ecosystems to promote human well-being and aims to devolve authority for ecosystem management to the local (community) level. CBNRM therefore requires strong investments in capacity development of local institutions and governance structures. CBNRM has come under strong criticism for its failures to deliver real benefits to communities. In this paper we explore the reasons for the frequent failure of CBNRM. We postulate that good governance buffers CBNRM against unexpected change, notably conflicts, especially in the early stages when income generation, infrastructure development and capacity development have not yet taken place. We assess the key characteristics of CBNRM governance systems that could perform this buffering function, using case study examples from Macubeni, Nqabara, Makuleke and Richtersveld to support our propositions. In our case studies, 11 strategies have been used to increase the incidence of success of CBNRM: understand and describe the social-ecological system; establish and communicate a clear vision; build on local organizations; plan ahead; create rules for resource use and enforce them; communicate the vision, plan and rules; develop management capacity; finance the initial stages of the initiative; work within available legal frameworks; monitor and learn all the time; and create lasting incentives. Despite these strategies there are, however, a number of obstinate implementation challenges, related to governance shortcomings and external factors which management cannot control. We therefore propose seven additional strategies to promote good governance in CBNRM:

1. Develop knowledge networks that draw on the experience and wisdom of a wide range of key individuals.

2. Establish formalised decision-making structures (e.g. multi-level project steering committees) with clear constitutions and codes of conduct.

3. Clearly define and legitimise conflict resolution procedures.

4. Ensure acceptance of the governance structure by community members.

5. Obtain formal commitment to well-defined roles and responsibilities by key individuals.

6. Establish tangible incentives to key individuals for meeting their commitments.
\end{abstract}

doi: 10.2166/wp.2007.132

(C) IWA Publishing 2007 
7. Develop the capacity for facilitation to promote communication.

Local communities, government and scientists have important roles to play in maintaining these knowledge and governance networks through adaptive co-management.

Keywords: Adaptive co-management; Case studies; Communal areas; Community-based Natural Resource Management (CBNRM); Ecosystems and human well-being; Governance; Knowledge networks; South Africa

\section{Introduction}

Community-based Natural Resource Management or CBNRM focuses on the collective management of ecosystems to improve human well-being. It aims to devolve authority for ecosystem management to the local (community) level, thereby empowering communities to manage their own resources without permanently damaging, depleting or degrading them. CBNRM therefore requires strong investments in capacity development and the development of local institutions and governance structures. More recently, CBNRM has come under strong criticism for its failures to deliver real benefits to communities and for the high incidence of collapse of CBNRM initiatives (Fabricius, 2004; Magome \& Fabricius, 2004). Governance has been identified as one of the key drivers (MA, 2003) of CBNRM (Borrini-Feyerabend, 1997; Agrawal, 2001; Bohensky et al., 2004; Koch, 2004; Bohensky \& Lynam, 2005), and many donors are now concentrating strongly on the governance and "adaptive co-management" components of project implementation.

While governance is inherent in the "Management" component of CBNRM, we postulate that certain aspects of governance are essential to buffer CBNRM against unexpected change and conflicts. This is especially relevant in the early stages of CBNRM initiatives when financial improvements, infrastructure development and capacity development have not yet taken place. We highlight the key characteristics of CBNRM governance systems that could perform this buffering function, using case study examples to support our propositions. We also assess the role of scientists, society and government in promoting good governance (i.e. "the trialogue") through the formation of learning networks for adaptive co-management (Salafsky et al., 2001; Olsson et al., 2004). First, we explore reasons for CBNRM's high incidence of failure (Campbell et al., 2001).

\section{Why does CBNRM often fail early on?}

CBNRM initiatives are notorious for their high rates of failure and the many problems that tend to besiege them, particularly in their early stages of development (Fabricius, 2004). We contend that the "teething problems" of CBNRM are due to shortages in critical types of capital in remote rural areas, where most CBNRM programmes are situated (Fabricius, 2004) and that CBNRM projects are therefore vulnerable to early shocks and surprise (Folke et al., 1998). Carney (1998) and the Department for International Development (DfID, 2000) identified five types of capital in people's livelihoods: natural capital (ecosystem goods and services); social capital (social and kinship networks and reciprocity, and social institutions); human capital (skills, knowledge and labour); physical capital (infrastructure and services) and financial capital (money or other financial assets) (Figure 1(a)). Natural and social capital, 

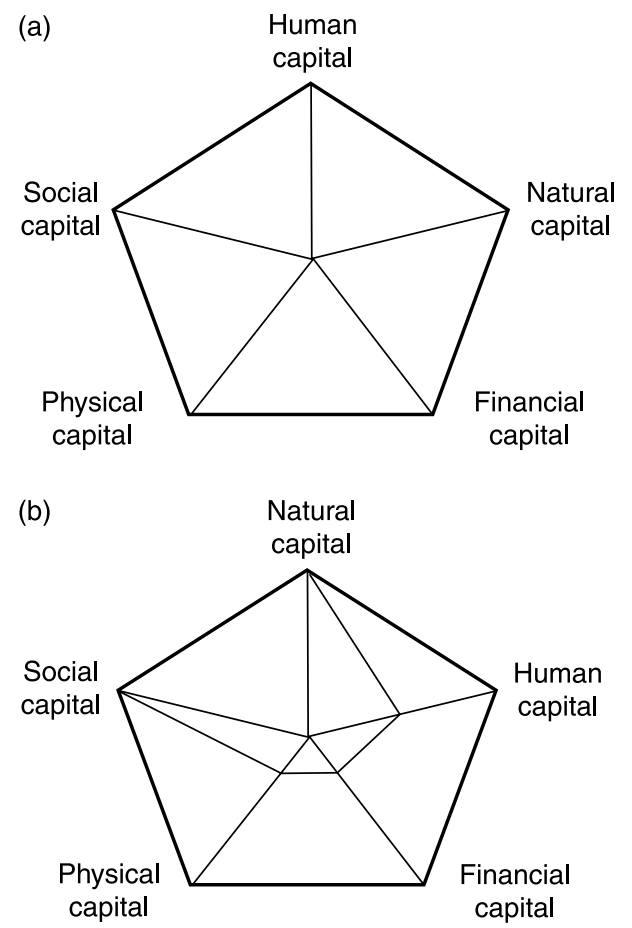

Fig. 1. The "asset pentagon" (DfID, 2000) representing: (a) an even distribution in the five types of capital and (b) an uneven distribution due to shortages in physical, financial and human capital, the "hard" types of capital required in CBNRM (see text).

being well represented in most CBNRM initiatives, constitutes CBNRM's key strengths. However, most initiatives are in impoverished, remote rural areas, where the "hard" types of capital: human capital (skills and education), financial capital and physical capital (infrastructure and services), are in short supply in CBNRM (Figure 1(b)). This shortage of "hard" capital makes CBNRM initiatives, and especially the institutions that are critical to CBNRM's functioning (Agrawal, 2001), vulnerable to external change.

Classic surprises that negatively affect CBNRM institutions are:

- Conflict. Conflict is one of the key proximate drivers of CBNRM, and many initiatives have been stalled or abandoned because of conflict. Koch (2004) outlines six types of conflict in CBNRM: competition for benefits at the time of success; competing livelihood strategies; tension between traditional authorities and elected leaders; conflict between entrepreneurs and collective action; the "fluidity" of communities; and the hidden power of spiritualists.

- Financial mismanagement. Communities are often unable to manage project revenues, resulting in unaccounted finances, corruption, mistrust and the reluctance of private sector partners to engage with them (Robbins, 2000).

- Mismanagement of natural resources. Often certain sectors in communities take advantage of their newly found rights and freedom to illegally use forest and wildlife resources for profit. This has an escalating effect, with other community members joining in the illegal activities for fear of "losing out" on their share of the resources (Okello \& Kiringe, 2004). 
- High turnover of leaders and other key players. Key role players frequently enthusiastically enter initiatives, use the experience and training to further their personal careers, and then leave. In other instances, mistrust and lack of progress cause role-players to become disillusioned, and motivating them to apply for positions elsewhere. Government is often to blame for transferring or promoting officials, often just as they start understanding the issues, gaining the trust of communities and showing progress (Fabricius \& McGarry, 2004).

- Political and economic change at higher levels. Changes in national politics, policy change, civil conflict and macro-economic change can cause even the best-managed initiatives to falter (Biggs et al., 2004). These external drivers are beyond the control of local communities and project managers, and projects can do little to prevent them from taking place.

- Changes in markets. The tourism market, in particular, can be quite volatile, and is influenced by external events such as crime, customer perceptions, competition, monetary exchange rates and global economic trends. Other markets, such as those for medicinal plants, food and fuel, are more stable but their generated revenues are a lot lower than those from tourism.

- Top-down developments. Grand schemes such as irrigation projects, infrastructure development, mega-protected areas and large-scale tourism developments often have unintended negative consequences for CBNRM (Biggs et al., 2004). This may lead to disempowerment, demographic shifts, competition, and environmental impacts that could have profound effects on CBNRM.

\section{Case studies in the development of governance systems in CBNRM}

Four case studies-Macubeni and Nqabara in Eastern Cape, the Makuleke area in Limpopo and the Richtersveld in the Northern Cape — are presented to investigate and assess the governance dimension of CBNRM.

\subsection{Macubeni, Eastern Cape}

Macubeni is situated in the Grassland Biome, near Queenstown in the Chris Hani District Municipality and Emalahleni local municipality. The local community consists of about 1690 households (almost 7500 individuals) living in 14 villages in a single ward. The area is part of the catchment of the Cacadu River, which supplies water to the Emalahleni local municipality, and is the most important source of drinking and irrigation water for more than 50 downstream villages. Historically, Macubeni was part of the former Transkei and has been affected by Betterment schemes, notably the construction of the Macubeni dam in the catchment in 1986 (Fabricius \& McGarry, 2004). The area is currently suffering from severe rangeland degradation, the out-migration of skilled people and a dire lack of infrastructure and services such as piped water, electricity and road networks. Land tenure is mainly communal and state-owned, although some parcels of land, such as certain fields, are privately owned (iKhwezi, 2003).

The key CBNRM challenges at Macubeni are to: prevent the causes of rangeland degradation by reducing grazing pressure by livestock; restore degraded areas, particularly wetlands and riparian areas; develop the management capacity of local decision-makers; and create incentives for ecosystem 
management by promoting small enterprises around plant cultivation and seed production, land restoration services, erosion control teams and water production. The long-term objective is to aim towards payment for ecosystem services, notably for increased carbon fixation, and increased water production from the catchment (Fabricius \& McGarry, 2004).

\subsection{Nqabara, Eastern Cape}

Nqabara is situated near Willowvale in the Mbhashe local municipality and Amatole District Municipality. The area was also affected by Betterment in the mid-1960s when many people were forced to move $2-5 \mathrm{~km}$ inland, away from the productive coastal zone. The community of about 600 households lives in 10 villages under a single traditional leader and in a single municipal ward. The highly productive and well-conserved ecosystem consists of a mosaic of coastal forests and grasslands, coastal dunes and estuaries intersected by rivers and drainage lines. The biodiversity value of the area is high and it has considerable tourism potential (Palmer et al., 2002; Mafa Environment \& Development, 2003). People are highly dependent on forests and grasslands for fuel, medicinal plants, grazing and natural resources for rituals. The land is communally managed and, like all communal areas in South Africa, state-owned.

Three key challenges for CBNRM at Nqabara are: the development of up-market nature tourism facilities in partnership with the private sector; the establishment of a community conservancy in partnership with government; and the cultivation and wholesale of medicinal plants in partnership with pharmaceutical companies.

\subsection{Makuleke, Limpopo}

The Makuleke Community consists of about 15,000 people living in three villages close to the Kruger National Park (KNP) fences just south of the Punda Maria Gate. In 1966 the community was forcibly removed from 22,000 ha of fertile land in what became the northernmost part of the KNP. Their removal was carried out as a part of the apartheid forced removals policies, but justified at the time in terms of the high levels of biodiversity on the land and the need to extend the KNP (Reid \& Turner, 2004). In 1996, using the new land reform program, the Makuleke community successfully reclaimed full ownership right on this 22,000 ha as well as another 5,000 ha which was not fenced into the Park. In the process of reclaiming their land, they agreed to keep their 22,000 ha as conservation land and to add the "outside" 5,000 hectares to the Kruger Park for 50 years (Fabricius \& de Wet, 2002). They did this on the basis that they would be able to use the conservation status to improve their lives outside the KNP. The state willingly agreed to this arrangement and gave the Makuleke land the status of a Schedule B national park, called a "contract park" (Reid \& Turner, 2004).

The community, in agreeing to keep their land as a conservation area, committed themselves not to use it for agriculture, mining or residence, all of which could be viable and luctrative. It should be noted that their piece of land forms the heart of the Greater Limpopo Transfrontier Park and will be the only direct link between South Africa and Zimbabwe. Through a series of partnerships with 
private hunters and tourism operators they raised substantial financial income and also facilitated over 100 permanent jobs. They are using the financial benefits from conservation to improve the lives of the community and have so far built additional classrooms, given bursaries to their youth, and electrified two villages.

An important part of Makuleke governance has been a co-management arrangement with the conservation agency, and the accompanying gradual handing over of land management and decisionmaking responsibilities to the Makuleke community. Good governance has also taken place at a community level, where they have tried to develop transparent and accountable institutions to faciliate benefit sharing. The key CBNRM challenges facing the Makuleke are: how to ensure that investments of income from the land are productive and not conflictual; how to reconcile the consumptive use of resources through trophy hunting with non-consumptive tourism; and how to develop village-based small businesses that capitalize on the increased tourism activity in the park.

\subsection{Richtersveld, Northern Cape}

The Richtersveld is an area in the Northen Cape bordered by the Atlantic Ocean on the West, the Orange River on the North and East and the road from Steinkopf to Port Nolloth on the South. The Gariep River which forms the northern bondary of the Richtersveld is also the border between South African and Namibia. The area is inhabited by a mixture of Nama and Baster people that live in four villages of about 500 people each, with an additional 2,000 residents in nearby Port Nolloth. While the Nama residents of the villages have been there for over a century, most residents in Port Nolloth came to the area after 1950, attracted by the diamond and fishing industries.

Geographically and botanically the area is a unique mountain desert nourished by the mist of the cold Atlantic, making it high in biodiversity endemism and an increasing attraction for tourists. Over the past 60 years the residents have been developing eco-tourism facilities and setting aside land for conservation purposes. In 2002 they proposed the protection of 160,000 ha of unspoilt land by forming a community conservancy (Nott \& Jacobsohn, 2004). They were one of the first communties to use the Integrated Development Plan (IDP) process as a way of allocating land for this purpose. The conservancy will border the Richtersveld National Park, also about 160,000 ha, which is the result of a contract signed between SANParks and the community in 1991. This park is part of a transfrontier conservation area between South Africa and Namibia.

The Richtersveld Communal Property Assocation, in a precedent setting case, won the right to compensation from the State for diamonds mined by the state-owned mining company Alexcor. They are still negotiating a settlement with the State (Reid \& Turner, 2004).

The key CBNRM challenges facing the Richterveld are: how to upscale the benefits from communitybased tourism, which is increasing but not resulting in many more jobs; how to best use the compensation package from the State and Alexcor to unite the community rather than divide them; how to deal with the long history of bad mining practices that has created environmental damage; and how to begin using the National Park as a real tourism asset that will create more than the 16 permanent jobs it currently provides. 


\section{Strategies to increase the likelihood of success}

From 1996 to 2002 GTZ, a German agency for technical cooperation, worked with both the Makuleke and Richtersveld communities through its Training and Support for Resource Management (Transform) programme. In 2002 Transform initiated a number of interventions at Nqabara and Macubeni to strengthen CBNRM, and to apply the lessons learnt at Richtersveld and Makuleke. The principles of these interventions in South Africa were carefully researched and documented prior to the interventions (Fabricius et al., 2003a) and supplemented by lessons from international and local experiences in CBNRM. These design principles are:

1. Understand and describe the social-ecological system. Baseline studies were conducted to understand the local history, dynamics and key social, institutional, ecological and economic strengths and weaknesses of CBNRM. A combination of participatory and conventional methods was used, and local capacity was developed by involving local people. A particular effort was made to understand the interactions and feedbacks between the different components of the socialecological system (Berkes \& Folke, 1998).

2. Establish and communicate a clear vision. Visioning facilitates mutual understanding and gives purpose (Olsson et al., 2004). Clear community visions were established, documented and regularly articulated. This was put into a Management and Development Plan (for the Makuleke) and in the IDP (in the Richtersveld).

3. Build on local organizations. Knowledge networks facilitate knowledge exchange and learning, and increases the resilience of local organizations (Olsson et al., 2004). Knowledge networks (Gadgil et al., 2003) were created, consisting of representatives of each of the respective villages, traditional leaders (in the case of Nqabara and Makulele but not Richtersveld and Macubeni), representatives of the local municipalities, the District Municipalities, provincial government and national government (Agriculture; Economic Affairs Environment and Tourism; Water Affairs and Forestry). Existing organizations such as the Nqabara PFM committee, Richtersveld CPA and Macubeni Livestock Owners Association and ward committees were incorporated into these structures.

4. Plan ahead. Goal-setting and planning and foresight is an integral part of the adaptive management cycle (Kay et al., 1999; Lessard, 1998). A land-use plan (in the case of Macubeni), a conservancy management plan (in the case of Nqabara and the Richtersveld) and a management and development plan (in the case of Makuleke) were developed. All plans had strong inputs from community members, and used a combination of technology (GIS, aerial photography) and "low-tech" methods such as participatory mapping and participatory learning and action.

5. Create rules for resource use (and enforce them). In communal areas with weak property rights, rules that exclude "outsiders" from using common pool resources can act as a substitute for property rights, which are an essential components of institutional development (Roy \& Tisdell, 1998). Rules for natural resource use, and penalties when they are broken, have been drawn up. Rules and codes of conduct are key components of common property management systems, and signify the difference between open access or a "Tragedy of the Commons" (Hardin, 1968) and common property management systems (Ostrom, 1990; Fabricius, 2004). Management plans with clear rules and boundaries were compiled for Richtersveld and Nqabara, and a land use plan was developed for Macubeni. These documents were drawn up with strong community participation and incorporation of local knowledge, supplemented by science. 
6. Communicate the vision, plan and rules. Communication deserves "serious attention" in adaptive co-management of natural resources (Vincent, 2003) and can take place at four levels: dialogue; reflection on history; "folk culture" such as drama, story telling and music; and diffusion of new knowledge. With the exception of folk culture, all forms of communication took place in the two case studies, albeit with a bias towards dialogue. Frequent communication and information meetings with local, provincial and national government role-players have taken place. A community communication initiative was launched at Nqabara, with information brochures and notices being circulated to households and displayed in prominent places. A community newsletter was published in both the Richtersveld and Makuleke.

7. Develop management capacity. The capacity for ecosystem management is essential for the development of resilient institutions and governance structures (Olsson, 2003; Folke et al., 2005). Capacity was developed through training courses (in the case of Macubeni and Makuleke), and in all cases through the planning process and on-going reflection and participatory planning and learning (Vernooy \& McDougall, 2003).

8. Finance the initial stages of the initiative. Although CBNRM should become independent of donor funds (Fabricius et al., 2001), seed funding is essential in the early stages of community-based initiatives, to compensate for the initial lack of financial capital elucidated earlier. Funds were raised from the national government's poverty relief grant to implement the conservancy and land use plans in the Eastern Cape. At Makuleke, donor money helped initially but as the private partnerships developed money raised by them was used.

9. Understand and work within available legal frameworks. Despite its broadness and inclusivity, CBNRM does not suffer from any shortages of policy or regulatory frameworks and existing policies seem to be adequate (Fabricius et al., 2003b). In all four cases, the Municipal Systems Act (Act No. 32 of 2000) provided the legal basis for the municipalities' participation. At Nqabara, forestry, environmental and conservation legislation have been included in the conservancy management plan and the Department of Land Affairs has initiated community resolution procedures for permission for land development. At Macubeni, legislation was used to define land and resource ownership. In the Richtersveld and Nqabara it is unclear exactly how the conservancies will be proclaimed, but existing legislation seems to be adequate.

10. Monitor and learn all the time. Monitoring is essential in adaptive collaborative management (Vernooy \& McDougall, 2003) and forms the basis for reflection and learning (Vincent, 2003). Monitoring programmes have been initiated at Nqabara and Macubeni, where the community has defined indicators and base-line data have been collected. At Makuleke, the success of community anti-poaching activities is being monitored. These monitoring programmes have three main objectives: (a) to learn about ecosystem management through adaptation and feedback; (b) to monitor the processes and activities associated with external interventions and local action; and (c) to assess the outcomes of management strategies and actions for ecosystems and human well-being.

11. Create lasting incentives. Lasting tangible incentives are essential for on-going natural resource management and the continued functioning of local institutions (Roy \& Tisdell, 1998; Jenkins \& Edwards, 2000; Milton et al., 2003; Roe, 2004). Although the CBNRM programmes at Nqabara, Richtersveld and Macubeni have been structured around a vision of long-term incentives and benefits from tourism (in the case of Nqabara) and ecosystem services (in the case of Macubeni), these have not yet materialized. At Makuleke, private investments and accompanying lease fees are finally delivering tangible benefits to the community. 


\section{Obstinate implementation challenges}

Despite this well-planned and structured intervention, a number of critical obstacles and challenges continue to threaten the success of these initiatives in the implementation stages. Most, if not all, of these obstacles relate to failed governance and, in particular, the failure of cooperative learning networks between scientists, government and local communities.

The slow pace of development. In all the referred-to case studies, the pace of development was initially over-estimated. Project managers and implementers did not realize how long the preparation stages would take, and even simple tasks allocated to the communities took longer than expected to complete because of low levels of human capital. Training took longer than expected because of local people's extremely weak initial capacity, and facilitators underestimated the need for day-to-day mentorship and under-budgeted for capacity development. The shortage of physical capital (e.g. telephone and electricity networks, poor road conditions) made progress even more difficult. Miscommunications around meeting dates and venues, the non-arrival of key stakeholders at meetings due to poor road conditions or shortage of transport, and the absence of office equipment (computers, printers, photocopiers, fax machines) are common and cause unexpected delays. Stronger cooperative governance structures could have anticipated these delays, discussed them and found timely solutions.

Weak participation by local, national and provincial government. Natural resource management is frequently situated in inappropriate municipal departments such as Health, whereas CBNRM logically belongs under Local Economic Development, or Planning directorates. Municipalities do not see CBNRM as a top priority, and provincial and national government departments are reluctant to prioritise CBNRM because of its relative novelty, and because it requires specialist staff with backgrounds and interests in the social sciences. Such human capital is scarce. Strong cooperative governance structures could have pooled human resources across sectors and learnt from each others' successes and failures.

Poor coordination. Despite facilitators' efforts in formulating local project steering committees and co-management structures, lack of coordination frequently bedevils project implementation. For example, stakeholders frequently unilaterally implement projects outside of agreed planning frameworks. This is often caused by a lack of internal communication by role-players, for example when a different directorate in a municipality implements a project that directly impacts on the CBNRM intervention without the knowledge of the municipality's representative on the project steering committee. Strong cooperative governance structures could have prevented this by communicating more frequently, discussing work plans and avoiding duplication.

Weak local and municipal governance structures. We have found that, while local institutions are essential for the formulation and implementation of local "codes of conduct" (Ostrom, 1990; Ostrom et al., 1999) associated with "informal" CBNRM (e.g. the everyday use of resources (Shackleton \& Shackleton, 2004)), they are invariably poorly equipped for formal administrative management. Social capital is well developed in rural communities, but it centres around social networks, rituals and reciprocity, rather than around formal governance. Retired people (mostly males) are traditionally the stalwarts of rural community organizations, but they are often illiterate and lack formal education. Very few young people attend meetings, and those present do not contribute to discussions because of traditional respectfulness of the young towards elders. Those with literacy and numeracy skills tend to be side-lined because of politics, gender relations and age hierarchies. Strong local organizations such as ward committees at Macubeni, the co-management committees and Communal Property Associations at 
Richtersveld and Makuleke, and a Development Committee at Nqabara do exist, but they have many priorities besides CBNRM. The same individuals also tend to be active in many different organizations, stretching their capacities to the limit. Traditional leadership structures can play an important institutional role in natural resource management (Tisdell, 1997), but they also play multiple roles and their legitimacy is frequently contested (Koch, 2004). At Macubeni, traditional leaders are, to a large extent, currently side-lined, while at Nqabara they have taken sides in a conflict and, as a result, are losing their legitimacy in certain villages. At Makuleke the Tribal Authority is involved through representation of the chief on the CPA executive as well as in the development forum, which prioritises spending of community income in the villages. Strong cooperative governance structures could have strengthened local and government organizations and prevented these shortcomings.

Conflict. One of the main causes of conflict was about how costs and benefits should be distributed. In most cases, local beneficiaries became embroiled in disagreements and outright conflict soon after the availability of project funding was announced. There were differences in communities about who should be trained, how fees should be distributed, how jobs should be shared and who should make which sacrifices. Because financial capital is in such short supply in rural communities, rural governance structures have not yet evolved mechanisms for dealing with financial greed. Rural "champions", who earlier worked hard to get projects off the ground, are often (and sometimes correctly) accused of enriching themselves. Strong cooperative governance structures could have anticipated such conflicts, and could have agreed in advance on conflict resolution procedures and mechanisms.

Historical legacies of separate development. The former Transkei (in the case of Macubeni and Nqabara) and Lebowa (in the case of Makuleke) "homeland" administrations had a history of manipulating rural opinion and support through top-down interventions and schemes, mostly employing strategies such as hand-outs and "command and control" interventions (De Wet, 1995). This was no different at Richtersveld, where a different but equally divisive and manipulative historical system was implemented for coloured people. These initiatives eroded rural black people's sense of self-belief and confidence in their own capabilities (Whyte, 1995), and most communities will take a long time to recover from the "dependence syndrome". Local people are therefore not yet confident about their ability to take their future in their own hands, and are still secretly hoping for the type of top-down projects that characterized the separate development era (Fabricius \& de Wet, 2002). Strong cooperative governance structures could build local people's capacity, gradually strengthening their confidence through cooperation and mutual learning.

\section{How can CBNRM be "buffered" against these challenges?}

In complex systems, buffers absorb change and therefore play an important role in improving the capacity of social-ecological systems to cope with political, economic and climatic change (Bellwood et al., 2004). The five types of capital (Figure 1) fulfil this buffering function, but their roles are not equally strong at all stages. Natural and social capital (the inherent strengths of CBNRM) are well-represented and strong in the early phases, but the "harder" types of capital (human, financial and physical capital) are invariably in short supply. It is therefore imperative to improve CBNRM's "hard" capital base without, of course, neglecting its key strengths of social and

natural capital. This is, however, a long-term objective which typically takes a decade or more to achieve (Magome \& Fabricius, 2004). 
In the short term, while the financial, physical and human capital base is being developed, strong and resilient governance systems are essential to buffer CBNRM against change and unexpected events. Governance in CBNRM comprises the social networks, organisational hierarchies, institutions (Agrawal, 2001) and decision-making structures that control the outcomes of CBNRM for human well-being and ecosystem integrity. Governance structures also maintain and strengthen social networks that form the basis for adaptable local institutions (Olsson et al., 2004) by building trust, formalizing relationships and maintaining communication. They can therefore put into effect the rules and codes of conduct associated with social institutions (Anderies et al., 2004), while monitoring compliance with these rules (Gottret \& White, 2001). Good governance systems are valuable in CBNRM because they can put the brakes on change (Colding et al., 2003) by managing and slowing down runaway conflict. They also act as the social-ecological "memory bank" of the system (Bohensky \& Lynam, 2005) by formally recording historical events and interventions and informally memorizing it. Good systems of cooperative governance can assist in re-organising the social and institutional components of CBNRM after collapse (Gunderson \& Holling, 2002) by mobilising human resources, raising funds and adjusting institutional arrangements.

It is therefore essential to invest heavily in the development of functioning and resilient governance systems in the early stages of projects, before conflict becomes a real problem and the obstacles listed above have surfaced. Many of these obstacles can be overcome by focusing on the following aspects of governance:

1. Knowledge networks that draw on experience and wisdom of a wide range of key individuals or "knowledge stewards" (Olsson, 2003) who work at different hierarchical levels. "Champions" need to be nurtured and responsibilities should be spread as widely as possible to avoid dependence on single individuals.

2. Formalised decision-making structures (e.g. multi-level project steering committees) with clear constitutions and codes of conduct, with clearly defined and officially endorsed terms of reference should be constituted. These structures should have dedicated representatives of local communities, all three tiers of government and technical specialists. The constitution should make provision for reelection of under-performing participants, and participation in these structures should be monitored and reported on.

3. Clearly defined and legitimised conflict resolution procedures, including acknowledged arbitrators and facilitators (Ostrom, 1990).

4. Legitimacy and acceptance of the governance structure by community members, traditional authorities, elected political representatives, municipal officials, and managers in provincial and national government (DEAT, 2003).

5. Formal commitment to well-defined roles and responsibilities by key individuals in the network. These responsibilities should be endorsed by supervisors and committed to in writing by key individuals, and they should be held accountable for failures to meet their commitments.

6. Tangible incentives to key individuals for meeting their commitments (Jenkins \& Edwards, 2000). This could take the form of formal recognition such as letters of appreciation (in the case of salaried officials), travel incentives to visit other CBNRM initiatives, training incentives and, in the case of unemployed community representatives, tangible rewards for tasks completed on brief and on time.

7. Professional facilitation to promote communication between participants in the knowledge network document the lessons learnt on an on-going basis, keep champions motivated and on board, manage 
conflicts before they have escalated, and remind key individuals of their commitments and responsibilities (Jones, 1999).

\section{The role of "the trialogue" in promoting good governance in CBNRM}

The trialogue, as a form of cooperative governance, can play an important role in overcoming the governance obstacles in CBNRM. The main benefit of the trialogue is in the facilitation of knowledge networks, where scientists, government and local communities can share information and together develop innovative solutions.

The role of local communities. Local communities are the primary resource users in CBNRM. Their governance role is to create and implement local codes of conduct for natural resource use, monitor trends in natural resources, and they benefit from CBNRM through improving their livelihoods and well-being. Local communities are able to detect fine-grained changes in ecosystems before any other stakeholders can, and are potentially able to respond to feedback from the ecosystem. However, as argued and demonstrated earlier, local communities lack the "hard" capital (skills infrastructure and finances) to respond to feedback from the ecosystem. A key role of the trialogue in CBNRM is to help strengthen human, physical and financial capital, to improve local communities' capacity to respond to ecological, economic and social feedbacks.

The role of scientists. In our experience, scientists' roles in CBNRM are to, firstly, collect and communicate data and information which is not immediately apparent to government officials and local communities, because it is either too coarse-grained (e.g. climate change), too fine-grained (e.g. the impact of fire intensity on vegetation) or too slow to observe (e.g. biodiversity loss). Secondly, scientists are also ideally positioned to communicate communities' knowledge and needs to policymakers and policy information to local communities, because of their ability and capacity to work at both policy and local community levels. Thirdly, scientists have access to technology such as Geographic Information Systems (GIS), satellite images, Global Positioning Systems (GPS) and mathematical or computer models, which can assist in forecasting, planning and monitoring.

The role of government. Much of the land in communal areas where most CBNRM initiatives take place is legally "owned" by government. The Department of Land Affairs therefore has jurisdiction over land development for, say, tourism and commercial forestry in communal areas. Many CBNRM initiatives are either adjacent to or on state conservation land, and therefore government or parastatal conservation organizations have important roles in CBNRM governance. Government, and local government in particular, is invariably the only formal governance institution mandated with long-term natural resource management in rural areas through, for example, IDPs, Local Economic Development plans, and implementing bioregional conservation strategies (Knight et al., 2003).

\section{Acknowledgements}

We thank the GTZ Transform programme and Johannes Baumgart for supporting the work leading to these lessons. The ideas expressed in this paper benefited greatly from discussions with CF's colleagues in the Resilience Alliance (www.resalliance.org) and the Millennium Ecosystem Assessment (www.maweb.org). 


\section{References}

Agrawal, A. (2001). Common property institutions and sustainable governance of resources. World Development, 29 , $1649-1672$.

Anderies, J. M., Jansson, M. A. \& Ostrom, E. (2004). A framework to analyse the robustness of social-ecological systems from an institutional perspective. Ecology and Society, 9, 18.

Bellwood, D. R., Hughes, T. P., Folke, C. \& Nystrom, M. (2004). Confronting the coral reef crisis. Nature, 429, $827-833$.

Berkes, F. \& Folke, C. (1998). Linking Social and Ecological Systems: Management Practices and Social Mechanisms for Building Resilience. Cambridge University Press, Cambridge.

Biggs, R. et al. (2004). Nature Supporting People. The Southern African Millennium Ecosystem Assessment Integrated Report. CSIR, Pretoria.

Bohensky, E. \& Lynam, T. (2005). Evaluating responses in complex adaptive systems: insights on water management from the Southern African Millennium Ecosystem Assessment (SAfMA). Ecology Society, 10(1), 11. Available at: http://www. ecologyandsociety.org/vol10/iss1/art11/.

Bohensky, E., Reyers, B., van Jaarsveld, A. S. \& Fabricius, C. (2004). Ecosystem Services in the Gariep Basin: A Basin-Scale Component of the Southern African Millennium Assessment. Sun Press, Stellenbosch, South Africa.

Borrini-Feyerabend, G. (1997). Beyond Fences: Seeking Social Sustainability in Conservation. IUCN, Kasparek Verlag, Gland, Switzerland.

Campbell, B., Mandondo, A., Sithole, B., De Jong, W., Luckert, M. \& Matose, F. (2001). Challenges to the proponents of common property resource systems: despairing voices from the social forests of Zimbabwe. World Development, 29, $589-600$.

Carney, D. (1998). Sustainable Rural Livelihoods- What Contribution Can We MakeDfID)? Department for International Development (DfID), London.

Colding, J., Elmqvist, T. \& Olsson, P. (2003). Living with disturbance: building resilience in social-ecological systems. In Navigating Social-Ecological Systems: Building Resilience for Complexity and Change. Berkes, F., Colding, J. \& Folke, C. (eds). Cambridge University Press, Cambridge, pp. 163-186.

De Wet, C. (1995). Moving Together, Drifting Apart: Betterment Planning and Villagisation in a South African Homeland. Witwatersrand University Press, Cape Town.

DEAT (Department of Environmental Affairs and Tourism) (2003). Guidelines For The Implementation of Community-based Natural Resource Management (CBNRM) in South Africa. Available at: http://www.environment.gov.za/Documents/ Documents/2003Sep12/cbnrm_12092003.html.

Department for International Development (DfID) (2000). Sustainable Livelihoods Guidance Sheets. Department for International Development, London.

Fabricius, C. (2004). The fundamentals of community-based natural resource management. In Rights, Resources and Rural Development: Community-based Natural Resource Management in Southern Africa. Fabricius, C., Koch, E., Magome, H. \& Turner, S. (eds). Earthscan, London, pp. 3-43.

Fabricius, C., Cundill, G. \& Sisitka, L. (2003a). Guidelines For The Implementation of Community-based Natural Resource Management in South Africa. Pretoria, DEAT and GTZ Transform, pp. 1-38.

Fabricius, C. \& de Wet, C. (2002). The influence of forced removals and land restitution on conservation in South Africa. In Conservation and Mobile Indigenous Peoples: Displacement, Forced Resettlement and Conservation. Chatty, D. \& Colchester, M. (eds). Berghahn Books, Oxford, pp. 149-165.

Fabricius, C., Koch, E. \& Magome, H. (2001). Community Wildlife Management in Southern Africa: Challenging the Assumptions of Eden. Evaluating Eden Series, IIED, London.

Fabricius, C., Matsiliza, B. \& Sisitka, L. (2003b). Laws, Policies, International Agreements and Departmental Guidelines that Support Community based Natural Resource Management Type Programmes in South Africa. Department of Environmental Affairs and Tourism and GTZ Transform, Pretoria, pp. 1-31.

Fabricius, C. \& McGarry, D. (2004). Frequently Asked Questions at Macubeni. GTZ Transform, Pretoria, pp. 1-12.

Folke, C., Berkes, F. \& Colding, J. (1998). Ecological practices and social mechanisms for building resilience and sustainability. In Linking Social and Ecological Systems. Berkes, F. \& Folke, C. (eds). Cambridge University Press, Cambridge, pp. 414-436. 
Folke, C,, Fabricius, C,, Cundill, G. \& Schulze, L. (2005). Communities, Ecosystems and Livelihoods. Millennium Ecosystem Assessment: Sub-global Volume. Millennium Ecosystem Assessment, Penang.

Gadgil, M., Olsson, P., Berkes, F. \& Folke, C. (2003). Exploring the role of local ecological knowledge in ecosystem management: three case studies. In Navigating Social-ecological Systems: Building Resilience for Complexity and Change. Berkes, F., Colding, J. \& Folke, C. (eds). Cambridge University Press, Cambridge, pp. 189-209.

Gottret, M. \& White, D. (2001). Assessing the impact of integrated natural resource management: challenges and experiences. Conservation Ecology, 5(2), 17. Available at: http://www.consecol.org/vol5/iss2/art17/.

Gunderson, L. H. \& Holling, C. S. (2002). Panarchy: Understanding Transformations in Human and Natural Systems. Island Press, Washington, DC.

Hardin, G. (1968). The tragedy of the commons. Science, 162, 1243-1248.

iKhwezi, (2003). Land Use Plan for the Macubeni Catchment, Emalahleni District, Eastern Cape. GTZ Transform, Pretoria, pp. $1-183$.

Jenkins, R. \& Edwards, S. (2000). Sustainable Use of Wild Species - A Guide for Decision Makers. IUCN Sustainable Use Specialist Group, Gland, pp. 1-14.

Jones, B. T. B. (1999). Community-based Natural Resource Management in Botswana and Namibia: An Inventory and Preliminary Analysis of Progress. Evaluating Eden Discussion Paper No. 6. IIED, London.

Kay, J., Regier, H., Boyle, M. \& Francis, G. (1999). An ecosystem approach for sustainability: addressing the challenge of complexity. Futures, 31, 721-742.

Knight, A. T., Boshoff, A. F., Cowling, R. M. \& Wilson, S. L. (2003). Keeping People on the Land in Living Landscapes: A Cooperative Strategy for Conserving Landscapes and Enhancing Livelihoods in the Subtropical Thicket Biome, South Africa. Report 46. Terrestrial Ecology Research Unit, Port Elizabeth, University of Port Elizabeth, South Africa.

Koch, E. (2004). Putting out fires: does the "C" in CBNRM stand for community, or centrifuge? Rights, Resources and Rural Development: Community-Based Natural Resource Management in Southern Africa. Fabricius, C. \& Koch, E. (eds). Earthscan, London, pp. 78-92.

Lessard, G. (1998). An adaptive approach to planning and decision-making. Landscape and Urban Planning, 40, 81-87. MA (2003). Ecosystems and Human Well-being: A Framework for Assessment. Island Press, Washington, DC.

Mafa Environment and Development (2003). Feasibility Assessment of PFM Projects in the Nqabara Administrative Area. GTZ Transform, Danida, DEAT and DWAF, Pretoria, pp. 1-94.

Magome, H. \& Fabricius, C. (2004). Reconciling biodiversity conservation with rural development: the Holy Grail of CBNRM? Rights, Resources and Rural Development: Community-based Natural Resource Management in Southern Africa. Fabricius, C., Koch, E., Magome, H. \& Turner, S. (eds). Earthscan, London, pp. 93-114.

Milton, S. J., Dean, W. R. J. \& Richardson, D. M. (2003). Economic incentives for restoring natural capital in southern African rangelands. Frontiers in Ecology and the Environment, 1, 247-254.

Nott, C. \& Jacobsohn, M. (2004). Key issues in Namibia's conservancy movement. In Rights, Resources and Rural Development: Community Based Natural Resource Management in Southern Africa. Fabricius, C., Koch, E., Magome, H. \& Turner, S. (eds). Earthscan, London, pp. 194-199.

Okello, M. M. \& Kiringe, J. W. (2004). Threats to biodiversity and their implications in protected and adjacent dispersal areas of Kenya. Journal for Sustainable Tourism, 12, 55-69.

Olsson, P. (2003). Building Capacity for Resilience in Social-Ecological Systems. PhD thesis, Stockholm University, Stockholm.

Olsson, P., Folke, C. \& Hahn, T. (2004). Social-ecological transformation for ecosystem management: the development of adaptive co-management of a wetland landscape in southern Sweden. Ecology and Society, 9(4), 2.

Ostrom, E. (1990). Governing the Commons: The Evolution of Institutions for Collective Action. Cambridge University Press, Cambridge.

Ostrom, E., Burger, J., Field, C. B., Norgaard, R. B. \& Policansky, D. (1999). Revisiting the commons: local lessons, global challenges. Science, 284, 278-282.

Palmer, R., Fay, D. \& Timmermans, H. (2002). From Conflict to Negotiation: Contested Resources on South Africa's Wild Coast. Human Sciences Research Council, Pretoria.

Reid, H. \& Turner, S. (2004). The Richtersveld and Makuleke Contractual Parks in South Africa: win-win for communities and conservation? Rights, Resources and Development: Community-based Natural Resource Management in Southern Africa. Fabricius, C., Koch, E., Magome, H. \& Turner, S. (eds). Earthscan, London, pp. 223-234. 
Robbins, P. (2000). The rotten institution: corruption in natural resource management. Political Geography, 19, $423-443$.

Roe, D. (2004). Millennium Development Goals and natural resources management: reconciling sustainable livelihoods and resource conservation or fuelling a divide? The Millennium Development Goals and Local Processes. International Institute for Environment and Development, London, pp. 55-73.

Roy, K. C. \& Tisdell, C. (1998). Good governance in sustainable development: the impact of institutions. International Journal of Social Economics, 23, 1310-1325.

Salafsky, N., Cauley, H., Balachander, G., Cordes, B., Parks, J., Margoluis, S., Bhatt, S., Encarnacion, C., Russell, D. \& Margoluis, R. (2001). A systematic test of an enterprise strategy for community-based biodiversity conservation. Conservation Biology, 15, 1585-1595.

Shackleton, C. \& Shackleton, S. (2004). Everyday resources are valuable enough for community-based natural resource management programme support: evidence from South Africa. In Rights, Resources and Rural Development: Communitybased Natural Resource Management in Southern Africa. Fabricius, C. \& Koch, E. (eds). Earthscan, London, pp. $135-146$.

Tisdell, C. (1997). Local communities, conservation and sustainability - institutional change, altered governance and Kant's social philosophy. International Journal of Social Economics, 24, 1361-1375.

Vernooy, R. \& McDougall, C. (2003). Principles of good practice in participatory research: reflecting on lessons from the field. In Managing Natural Resources for Sustainable Livelihoods: Uniting Science and Participation. Pound, B., Snapp, S., McDougall, C. \& Braun, A. (eds). Earthscan, London, pp. 113-141.

Vincent, L. (2003). Participatory research, natural resource management and rural transformation: more lessons from the field. In Managing Natural Resources for Sustainable Livelihoods: Uniting Science and Participation. Pound, B., Snapp, S., McDougall, C. \& Braun, A. (eds). Earthscan, London, pp. 142-168.

Whyte, A. (1995). Building a New South Africa: Environment, Reconstruction and Development. International Development Research Centre, Ottawa, Canada. 